\title{
EFEKTIVITAS PELAKSANAAN PROGRAM BKR DI DESA AIR LESING KECAMATAN MUARA BELITI KABUPATEN MUSI RAWAS
}

\author{
Ahmad Basri ${ }^{1}$, Priatin $^{2}$, Nasruddin $^{3}$, Syamsah Nas $^{4}$, Zulfikar $^{5}$ \\ ${ }^{1,2,3}$ Program Studi Manajemen, Universitas Bina Insan, Lubuklinggau \\ E-mail : ${ }^{1}$ atinsurya488@ gmail.com, ${ }^{2}$ nasruddin@ univbinainsan.ac.id, \\ 3syamsah@univbinainsan.ac.id
}

\begin{abstract}
ABSTRACK
Based on the motivation aspect of the members, it is not seen that the quality assessment of the quality of the Youth Family Development cadres is positive, while the empowerment aspect of the members is also not maximal in the application of trust and communication to the cadre members of the Youth Family Development from the organizing committee. So it can be concluded that the motivation of members and empowerment of members of Air Lesing Village Youth Families is not effective.
\end{abstract}

Keywords : Effectiveness, Implementation, Adolescent Family Development

\begin{abstract}
ABSTRAK
Berdasarkan aspek motivasi anggota tidak terlihat kualitas penilaian kualitas yang positif dari kader Bina Keluarga Remaja sedangkan aspek pemberdayaan anggota juga tidak maksimal dalam penerapan kepercayaan dan komunikasi kepada kader anggota Bina Keluarga Remaja dari pihak panitia penyelenggara. Sehingga dapat ditarik kesimpulan Motivasi anggota dan Pemberdayaan anggota Bina Keluarga Remaja Desa Air Lesing tidak efektif.
\end{abstract}

Kata kunci : Efektivitas, Pelaksanaan, Bina Keluarga Remaja 


\section{PENDAHULUAN}

Program Bina Keluarga Remaja ini dijadikan sebagai salah satu kegiatan yang sangat strategis dalam mengupayakan peningkatan pengetahuan dan keterampilan keluarga dalam mengasuh dan membina tumbuh kembang remaja melalui peran orang tua dalam keluarga. Dalam pengelolaan Program Bina Keluarga Remaja didasarkan pada Peraturan Kepala BKKBN Nomor 109/PER/F2/2012. Program ini dibuat melalui kelompok yang ada di setiap daerah di seluruh Indonesia, karena apa yang terjadi dengan remaja tidak hanya terjadi di satu daerah melainkan telah berkembang di seluruh penjuru negeri. Berdasarkan hal tersebut, BKKBN berusaha meningkatkan kualitas dari kelompok Bina Kelurga Remaja melalui kegiatan yang telah diatur, agar setiap kelompok yang terbentuk mampu menerapkan Program ini secara efektif. Berikut laporan tentang jumlah kelompok Bina Keluarga Remaja di Indonesia.

Berdasarkan hasil observasi awal yang peneliti lakukan di Bidang Ketahanan dan Kesejahteraan Keluarga Dinas Pengendalian Penduduk dan Keluarga Berencana Kabupaten Musi Rawas tentang jumlah kelompok Bina Keluarga Remaja di Kabupaten Musi Rawas sampai bulan Oktober Tahun 2019 tercatat ada 193 kelompok yang tersebar di 14 Kecamatan di Kabupaten Musi Rawas, dengan rincian sebagai berikut :

Tabel 1

Jumlah Kelompok Bina Keluarga Remaja Kabupatem Musi Rawas Tahun 2019

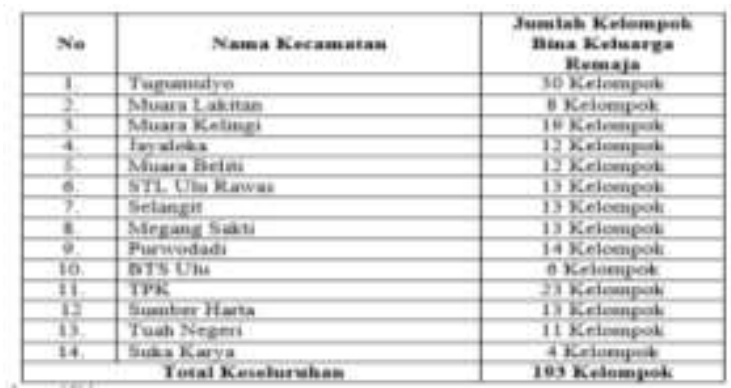

Sumber : (BKKBN, Jumlah Kelompok BKR di Indonesia, 2019)
Berdasarkan rincian tabel di atas dapat dilihat bahwa setiap Kecamatan di Kabupaten Musi Rawas memiliki kelompok Bina Keluarga Remaja (BKR). Namun tak sedikit pula, penerapan Program Bina Keluarga Remaja ini masih sebatas kelompok dan belum ada pergerakan dan pembinaan kelompok yang maksimal. Hal ini yang harus menjadi bahan evaluasi bagi Dinas Pengendalian Penduduk dan Keluarga Berencana (DPP-KB) Kabupaten Musi Rawas agar tujuan dari Program Bina Keluarga Remaja ini tercapai.

Para orang tua yang berada di Desa Air Lesing hampir sebagian waktu dalam satu hari mereka habiskan di ladang sehingga anak mereka yang terus tumbuh kembang tidak mendapatkan perhatian secara intensif. Karena kebutuhan anak bukan hanya pangan dan materil melainkan pengetahuan yang positif dari orang tua mereka. Inilah yang menjadi tujuan utama dari Program Bina Keluarga Remaja yang dicanangkan oleh BKKBN (Badan Kependudukan dan Keluarga Berencana Nasional) melaui DPPKB (Dinas Pengendalian Penduduk dan Keluarga Berencana) Kabupaten Musi Rawas agar orang tua mengetahui apa yang menjadi peran utama orang tua dalam pembinaan anak remaja mereka terutama terhadap tumbuh kembang remaja.

Dari penjabaran diatas, hal ini yang harus menjadi perhatian Dinas Pengendalian Penduduk dan Keluarga Berencana (DPPKB) Kabupaten Musi Rawas di Bidang Ketahanan dan Kesejahteraan Keluarga untuk melihat Efektivitas Program Bina Keluarga Remaja dengan menugaskan Korlap KB (Koordinator Lapangan Keluarga Berencana) yang tugas dan fungsinya antara lain adalah melakukan pembinaan dan mengkoordinasikan pelaksanaan Program Bina Keluarga Remaja terhadap institusi masyarakat yang terkait melalui keefektifan kelompok Bina Keluarga Remaja, agar tujuan dari Program Bina Keluarga Remaja tersebut dapat menuju sasaran yang tepat 
dengan menerapkan pelaksanaan Program yang telah disusun oleh BKKBN (Badan Kependudukan dan Keluarga Berencana Nasional) melalui DPP-KB (Dinas Pengendalian Penduduk dan Keluarga Berencana) Kabupaten Musi Rawas.

Atas dasar pemikiran dan asumsi sebagaimana di uraikan di atas, maka penulis tertarik untuk melakukan penelitian mengenai "Efektivitas Pelaksanaan Program Bina Keluarga Remaja Di Desa Air Lesing Kecamatan Muara Beliti Kabupaten Musi Rawas melalui motivasi anggota dan pemberdayaan anggota.

Dari hasil penelitian sebelumnya hampir semuanya menerangkan bahwa program BKR tidak efektif dalam pelaksanaannya serta pembinaan anggotanya. Banyak hal yang melatarbelakanginya sehingga program ini tidak mencapai kata efektif dalam pelaksanaan kegiatannya. Hal ini yang peneliti jadikan bahan yang relevan dengan apa yang diteliti.

\section{TINJAUAN PUSTAKA}

\subsection{Efektivitas}

Efektivitas dianggap sebagai suatu keadaan dan kemampuan berhasilnya suatu kerja yang dilakukan oleh manusia untuk memberikan guna yang diharapkan. Menurut para ahli Efektivitas adalah kemampuan untuk memilih tujuan yang tepat atau peralatan yang ada untuk mencapai tujuan yang telah ditetapkan. Sedangkan pengertian efektivitas yang dijadikan sebagai kemampuan untuk memilih sasaran yang tepat juga dipaparkan oleh para ahli sehingga efektivitas lebih mengarah pada kemampuan dalam memilih sasaran sehingga tujuan yang telah ditentukan dapat tercapai. Efektivitas juga diartikan sebagai pemanfaatan sumber daya, sarana dan prasarana dalam jumlah tertentu yang secara sadar ditetapkan sebelumnya untuk menghasilkan sejumlah barang atas jasa kegiatan yang dijalankan.
Efektivitas menunjukan keberhasilan dari segi tercapai tidaknya sasaran yang telah ditetapkan. Jika hasil kegiatan semakin mendekati sasaran, berarti semakin tinggi efektivitasnya. Kata efektivitas juga didefinisikan sebagai suatu tingkatan dalam hal keberhasilan yang dihasilkan oleh seseorang atau organisasi dengan cara tertentu sesuai dengan tujuan yang hendak di capai.

Dari beberapa pendapat di atas, dapat disimpulkan bahwa efektivitas merupakan suatu cara berupa kemampuan memilih sasaran yang tepat dan benar yang dimiliki oleh seseorang untuk mengelolah organisasi maupun kelompok agar dapat tercapainya tujuan yang diharapkan. Efektivitas juga dijadikan sebagai unsur pokok untuk mencapai tujuan atau sasaran yang telah ditentukan di dalam setiap organisasi, kegiatan ataupun program.

\subsection{Program}

Program dianggap sebagai unsur pertama yang harus ada demi terciptanya suatu kegiatan. Di dalam program dibuat beberapa aspek yaitu mengenai tujuan kegiatan yang akan dicapai, kegiatan yang diambil dalam mencapai tujuan, aturan yang harus dipegang dan prosedur yang harus dilalui, perkiraan anggaran yang dibutuhkan serta diperlukannya strategi pelaksanaan

\subsection{Pelaksanaan}

Pelaksanaan adalah kegiatan meliputi menentukan, mengelompokan, mencapai tujuan, penugasan orang-orang dengan memperhatikan lingkungan fisik, sesuai dengan kewenangan yang dilimpahkan terhadap setiap individu untuk melaksanakan kegiatan tersebut. Pelaksanaan juga dapat diartikan sebagai keputusan kebijakan dasar, biasanya dalam bentuk undang-undang, namun dapat pula berbentuk perintah atau keputusan badan eksekutif yang penting ataupun keputusan peradilan. 


\subsection{Program Bina Keluarga Remaja}

Program Bina Keluarga Remaja dijadikan sebagai suatu wadah yang berupaya untuk mendapatkan pemahaman orang tua dalam mendidik anak remaja yang benar yang dilakukan dalam bentuk kelompok - kelompok kegiatan, dimana orang tua mendapatkan informasi dan pengetahuan tentang bagaimana meningkatkan dan membina tumbuh kembang anak remaja.

Dengan demikian dapat disimpulan bahwa Program Bina Keluarga Remaja adalah Program yang dibuat bertujuan untuk membentuk karakter remaja melalui keluarga dan pola asuh orang tua. Proses pola asuh orang tua meliputi kedekatan orang tua dengan remaja, pengawasan orang tua, dan komunikasi orang tua dengan remaja. Sehubungan dengan hal tersebut, maka pengembangan kelompok Bina Keluarga Remaja dapat membantu orang tua dalam meningkatkan pengetahuan dan keterampilan orang tua dan anggota keluarga lainnya dalam pengasuhan dan pembinaan tumbuh kembang remaja.

\subsection{Motivasi Anggota}

Motivation menjelaskan mengapa seseorang tidak akan melakukan sesuatu yang ia yakini ia tidak dapat melakukannya, sekalipun hasil dari pekerjaan itu sangat dapat ia inginkan. Sehingga tinggi rendahnya motivasi seseorang ditentukan oleh tiga komponen yaitu :

1. Ekspektasi

2. Instrumentalis

3. Valensi

\subsection{Pemberdayaan Anggota}

Pemberdayaan merupakan pemberian tanggung jawab dan wewenang terhadap pekerjaan untuk mengambil keputusan menyangkut semua pengembangan produk dan pengambilan keputusan pemberdayaan erat hubungannya dengan profesionalisme yang pada awalnya selalu dimiliki oleh individual. Pemberdayaan di jadikan sebagai upaya mendorong dan memungkinkan individuindividu untuk mengemban tanggung jawab pribadi atas upaya mereka memperbaiki cara mereka dan menyumbang pada pencapaian tujuan-tujuan organisasi.

Pemberdayaan adalah upaya yang membangun daya masyarakat dengan mendorong, memotivasi dan membangkitkan kesadaran akan potensi yang dimiliki serta berupaya untuk mengembangkannya. Berarti mendorong mereka menjadi lebih terlibat dalam keputusan dan aktivasi yang memenuhi pekerjaan mereka. Dengan demikian, berarti memberi mereka kesempatan untuk menunjukkan bahwa mereka dapat memberi gagasan baik dan mempunyai keterampilan mewujudkan gagasan menjadi realitas.

Pemberdayaan sendiri memiliki model empowrment yaitu :

1. Desire

2. Trust

3. Confident, and

4. Communication

\subsection{Penelitian yang relevan}

Menurut Ira Puspita Sari dalam penelitiannya yang berjudul Efektivitas Pelaksanaan Program Bina Keluarga Remaja Pada Badan Pemberdayaan Perempuan dan Keluarga Berencana di Kecamatan Medan Deli : "Pelaksanaan Program BKR di Kecamatan Medan Deli sudah berjalan namun belum dapat dikatakan efektif. Hal ini terlihat dari kegiatan penyuluhan tidak rutin dilakukan setiap bulan, sosialisasi yang diberikan belum merata dan tidak adanya penyediaan sarana dan prasarana kegiatan. Sehingga belum dapat memberikan pemahaman kepada orang tua tentang materi substansi BKR. " Dari hasil penelitian di atas disimpulkan bahwa yang menjadi penyebab tidak efektifnya Program BKR di Kecamatan Medan Deli adalah tidak rutinnya kegiatan penyuluhan, sosialisasi yang diberikan tidak 
merata serta sarana dan prasarana tidak disediakan oleh Badan Pemberdayaan Perempuan dan Keluarga Berencana di Kecamatan Medan Deli selaku pihak penyelenggara Program BKR di Kecamatan Medan Deli. Hal ini menunjukkan bahwa Program BKR yang telah ditetapkan oleh BKKBN tidak sepenuhnya sesuai dengan prosedur yang ditetapkan oleh BKKBN. Kendala terbesar dari pelaksanaan Program BKR ini adalah pelaksana dari Program BKR itu sendiri, yang tidak maksimal dalam mengupayakan pencapaian tujuan Program BKR.

Dwi Wiliantining Pyas1 Dan Lena Satlita2 Dalam Jurnalnya Yang Berjudul Efektivitas Pelaksanaan Program Generasi Berencana Dalam Meningkatkan Kesehatan Reproduksi Remaja Di Kota Yogyakarta :

"Pelaksanaan Program Generasi Berencana (GenRe) di Kota Yogyakarta belum efektif dilihat dari lima indikator: (1) Kebijakan belum efektif dalam mengatasi permasalahan remaja. (2) Pelaksana cukup efektif dilihat dari pembagian tugas dan kewenangan meskipun memiliki keterbatasan sumberdaya manusia, (3) Target belum efektif karena target yang diintervensi belum siap mendukung Program GenRe, (4) Lingkungan kebijakan sudah efektif namun lingkungan ekternal belum efektif, dan (5) Proses belum efektif karena remaja dan keluarga yang mempunyai remaja belum memahami substansi Program GenRe. Faktor pendukungnya yaitu kemudahan dari komunikasi dan adanya pelatihan konseling. Beberapa penghambat antara lain rendahnya partisipasi masyarakat, adanya penyimpangan moral, dan keterbatasan waktu".

Dari hasil penelitian di atas dapat disimpulkan bahwa kebanyakan Program GenRe belum beroperasional secara maksimal dengan berbagai macam alasan dari pihak terkait dan masyarakat setempat yang tidak mendukung akan Program yang telah dicanangkan oleh Pemerintah untuk kesehatan remaja.

Fenicia Desiana Saragih dalam penelitiannya yang berjudul Peran Bina Keluarga Remaja (BKR) Dalam Mewujudkan Keharmonisan Keluarga Di Kelurahan Durian Payung Kecamatan Tanjung Karang Pusat Bandar Lampung: "Hasil penelitian ini menunjukkan bahwa Bina Keluarga Remaja memiliki peran sebagai fasilitator, motivator dan katalisator. Penyuluhan yang dilakukan Bina Keluarga Remaja berpengaruh terhadap terwujudnya keharmonisan keluarga di kelurahan durian payung kecamatan tanjung karang pusat. Adapun faktor penghambat adalah masih kurangnya kesadaran pasangan usia untuk ikut berpartisipasi dan masih kurangnya sarana dan prasarana untuk menunjang kegiatan Bina Keluarga Remaja. Faktor pendukung adanya semangat dan kerjasama yang baik dari setiap kader, kemudian di dukung oleh Petugas Lapangan Keluarga Berencana (PLKB) yang mendampingi dan membantu kader dalam melaksanakan kegiatan Bina Keluarga Remaja".

Berdasarkan hasil penelitian di atas dapat disimpulkan bahwa program Bina Keluarga Remaja memiliki peran yang sangat penting dalam meningkatkan keharmonisan keluarga. Karena pendekatan yang dilakukan oleh BKR kepada Orang tua yang memiliki anak remaja yang menjadi sasaran program BKR. dengan kualitas terbaik dari kader-kader BKR maka program BKR ini dapat langsung menyentuh tujuan dari program BKR yang ditargetkan kepada orang tua yang memiliki anak remaja.

\subsection{Tabel dan Grafik}

1. Tabel Penelitian

\section{Tabel 1}

Jumlah Kelompok BKR

Tahun 2019

\begin{tabular}{|c|l|r|r|}
\hline No & \multicolumn{1}{|c|}{$\begin{array}{c}\text { Nama } \\
\text { Provinsi }\end{array}$} & $\begin{array}{c}\text { Jumlah } \\
\text { BKR }\end{array}$ & $\begin{array}{c}\text { Jumlah Bina } \\
\text { Keluarga } \\
\text { Remaja aktif }\end{array}$ \\
\hline 1. & Aceh & 504 & 418 \\
\hline 2. & Sumatera & 433 & 335 \\
\hline
\end{tabular}


p-ISSN : 2527-7243, e-ISSN : 2721-6772

\begin{tabular}{|c|c|c|c|c|c|c|c|}
\hline & Utara & & \multirow{3}{*}{115} & \multicolumn{2}{|r|}{ Utara } & \multirow[b]{2}{*}{16} & \multirow[b]{2}{*}{0} \\
\hline \multirow[t]{2}{*}{3.} & \multirow{2}{*}{$\begin{array}{l}\text { Sumatera } \\
\text { Barat }\end{array}$} & \multirow{2}{*}{239} & & 33. & Papua & & \\
\hline & & & & 34. & Papua Barat & 81 & 51 \\
\hline 4. & Riau & 120 & 119 & \multirow{2}{*}{\multicolumn{2}{|c|}{$\begin{array}{c}\text { Jumlah } \\
\text { Keseluruhan }\end{array}$}} & \multirow[t]{2}{*}{19.596} & \multirow[t]{2}{*}{11.437} \\
\hline 5. & Jambi & 271 & 107 & & & & \\
\hline
\end{tabular}

Sumber : (BKKBN, Jumlah Kelompok BKR di Indonesia, 2019)

\section{Tabel 2}

Jumlah Kelompok BKR di Kabupaten Musi rawas

\begin{tabular}{|c|l|c|}
\hline No & \multicolumn{1}{|c|}{$\begin{array}{c}\text { Nama } \\
\text { Kecamatan }\end{array}$} & $\begin{array}{c}\text { Jumlah Kelompok } \\
\text { BKR }\end{array}$ \\
\hline 1. & Tugumulyo & 30 Kelompok \\
\hline 2. & Muara Lakitan & 8 Kelompok \\
\hline 3. & Muara Kelingi & 19 Kelompok \\
\hline 4. & Jayaloka & 12 Kelompok \\
\hline 5. & Muara Beliti & 12 Kelompok \\
\hline 6. & STL Ulu Rawas & 13 Kelompok \\
\hline 7. & Selangit & 13 Kelompok \\
\hline 8. & Megang Sakti & 13 Kelompok \\
\hline 9. & Purwodadi & 14 Kelompok \\
\hline 10. & BTS Ulu & 6 Kelompok \\
\hline 11. & TPK & 23 Kelompok \\
\hline 12 & Sumber Harta & 13 Kelompok \\
\hline 13. & Tuah Negeri & 11 Kelompok \\
\hline 14. & Suka Karya & 4 Kelompok \\
\hline Total Keseluruhan & $\mathbf{1 9 3 ~ K e l o m p o k}$ \\
\hline
\end{tabular}

Sumber : (DPP-KB, Jumlah Kelompok BKR

Musi Rawas, 2019)

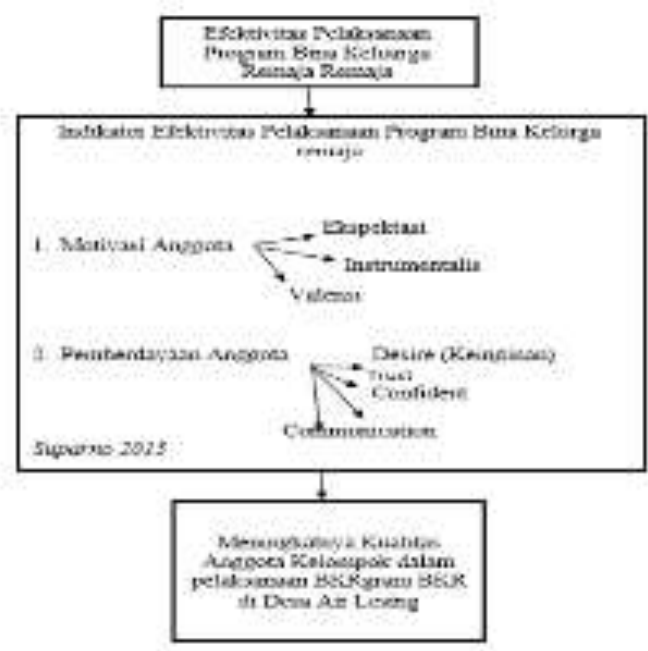

Gambar 1

Kerangka Berpikir 
p-ISSN : 2527-7243, e-ISSN : 2721-6772

Tabel 3

Profil Kelompok BKR Desa Air Lesing

\begin{tabular}{|c|c|c|c|c|c|}
\hline \multirow[t]{2}{*}{$\mathrm{x}$} & \multirow[t]{2}{*}{ Kama } & \multirow{2}{*}{$\begin{array}{l}\text { Penditikn } \\
\text { Ternbhir }\end{array}$} & \multirow[t]{2}{*}{ Jabatza } & \multicolumn{2}{|c|}{$\begin{array}{l}\text { Pemah Mendapat } \\
\text { Pehathan BKR }\end{array}$} \\
\hline & & & & Pemnh & Belum \\
\hline 1 & Nining & SMA & $\begin{array}{l}\text { Rata } \\
\text { kelonpok BKR } \\
\text { Des,Air } \\
\text { Leing }\end{array}$ & $\sqrt{ }$ & \\
\hline 2 & Listu Rina & S.P & $\begin{array}{l}\text { Sekretaris } \\
\text { kelingok BKR } \\
\text { Desa Air } \\
\text { Lesing } \\
\end{array}$ & 1 & \\
\hline 3. & Ianyen & S.P & $\begin{array}{l}\text { Benichara } \\
\text { kelonpok BKR } \\
\text { Des.Air } \\
\text { Leing }\end{array}$ & $\sqrt{ }$ & \\
\hline 4 & Harts & S.P & $\begin{array}{l}\text { Arogoda } \\
\text { kelonpdi BKR } \\
\text { Desa Air } \\
\text { Lesing }\end{array}$ & $\sqrt{ }$ & \\
\hline 5 & Murimsh & S.P & $\begin{array}{l}\text { Aroguta } \\
\text { helompkik BKR } \\
\text { Dess Air } \\
\text { Lesing }\end{array}$ & $\sqrt{ }$ & \\
\hline 6. & Sit Tursinah & SIA & $\begin{array}{l}\text { frogota } \\
\text { kelompd BKR } \\
\text { Dess Air } \\
\text { Lesing } \\
\end{array}$ & $\sqrt{ }$ & \\
\hline
\end{tabular}

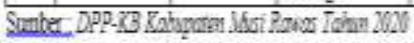

Tabel 4

Temuan Penelitian

\begin{tabular}{|c|c|c|}
\hline Xo & Tenusan Pencilina & Zetragera \\
\hline 1 & 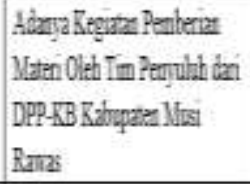 & 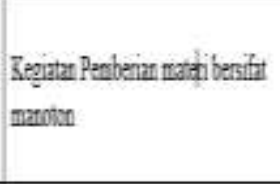 \\
\hline 2 & 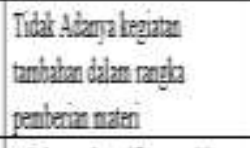 & 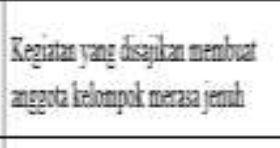 \\
\hline 3. & 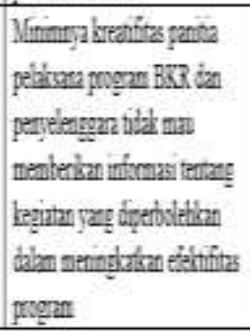 & 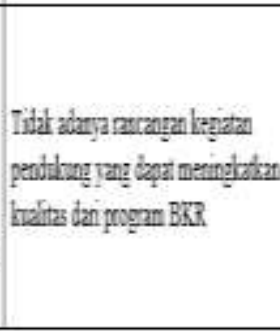 \\
\hline
\end{tabular}

Sumber : Data diolah, 2020

\section{Tabel 5}

Informasi Pelatihan Pengelolah BKR Kecamatan Muara Beliti

\begin{tabular}{|c|c|c|c|c|}
\hline \multirow{2}{*}{$\mathrm{N}_{0}$} & \multirow{2}{*}{ Nampes } & \multicolumn{2}{|c|}{ Perah Vendapt Pelothn BXR } & \multirow{2}{*}{ Beternge } \\
\hline & & Sulah & Behan & \\
\hline 1. & Tampend I & 1 & & \\
\hline 2 & AirSatan & 1 & & \\
\hline 3. & $B=A g a g$ & 1 & & \\
\hline 4. & Betua Ira & 1 & & \\
\hline 5. & Manh Resmi & 1 & & \\
\hline 6. & Mean BelfiBar & 1 & & \\
\hline 7. & Petagy & 1 & & \\
\hline 8. & ArLesing & 1 & & \\
\hline 9. & Drian Rect & 1 & & \\
\hline 10. & Dasia Saro & 1 & & \\
\hline 11. & Strm Latah Joga & 1 & & \\
\hline 12 & $\begin{array}{l}\text { Bel Pasa Lara } \\
\text { Belhi }\end{array}$ & 1 & & \\
\hline
\end{tabular}

Sumber : (DPP-KB, Jumlah Kelompok BKR Musi Rawas, 2019)

\section{Tabel 6}

Daftar Materi Pengetahuan Anggota BKR

\begin{tabular}{|c|c|c|}
\hline No & Mten Pergetahon & Keteragan \\
\hline 1. & $\begin{array}{l}\text { Pera Oreg Tra dabm Pectim ad } \\
\text { reng }\end{array}$ & \multirow{7}{*}{ Behan terealsai } \\
\hline 2 & Taldakehenseng & \\
\hline 3. & 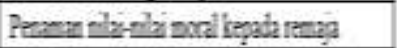 & \\
\hline 4. & Batarn ieprodksiresa & \\
\hline 5. & Nachoba dan nisan kero & \\
\hline 6. & HIIIADS & \\
\hline 2 & Penechlonga andremg & \\
\hline
\end{tabular}

Sumber : (DPP-KB, Jumlah Kelompok BKR Musi Rawas, 2019)

Tabel 7

Informan Penelitian

\begin{tabular}{|c|c|}
\hline Informan & Status/Jabatan Informan \\
\hline Ctama & Ketha Kelompok BKR Desa Air Lesing \\
\hline Pectukugg & $\begin{array}{l}\text { 1. KABD Ketahanan dan Resejahteraan Reluarga } \\
\text { DPP-KB Kabupaten Musi Rawas } \\
\text { 2. Korlap-KB area Kecamatan Muara Beliti } \\
\text { 3. Relompol Bira Keluarga Remaja Desa Air Lesing } \\
\text { 4. Masyarakat Desa Air Lesing }\end{array}$ \\
\hline
\end{tabular}

Sumber : (DPP-KB, Jumlah Kelompok BKR Musi Rawas, 2019) 


\section{METODOLOGI PENELITIAN}

(Sugiyono, 2017) Rancangan penelitian yang akan digunakan dalam penelitian ini adalah Deskriptif Kualitatif. Interaksi para masyarakat dan kelompok BKR yang akan dikaji dan diinterpretasikan oleh peneliti. Penelitian kualitatif menempatkan pokok kajiannya pada suatu organisasi atau individu seutuhnya.

Penelitian kualitatif lebih mengutamakan penggunaan logika induktif dimana kategorisasi dilahirkan dari perjumpaan peneliti dengan informan di lapangan atau data-data yang ditemukan. Sehingga penelitian kualitatif bercirikan informasi yang berupa ikatan konteks yang akan menggiring pada pola-pola atau teori yang akan menjelaskan fenomena sosial. Adapun jenis pendekatan penelitian ini dipaparkan secara deskriptif. Peneliti berusaha untuk menuturkan pemecahan masalah yang ada sekarang berdasarkan data-data. Jenis penelitian deskriptif kualitatif yang digunakan pada penelitian ini dimaksudkan untuk memperoleh informasi mengenai pelaksanaan program Bina Keluarga Remaja di Desa Air Lesing Kecamatan Muara Beliti Kabupaten Musi Rawas. Adapun dalam penelitian ini, peneliti membuat subyek penelitian yang dijadikan sebagai informan yang peneliti jadikan sumber informasi untuk mengetahui kualitas dari program BKR tersebut.

Metode Pengumpulan data dalam penelitian ini melalui Observasi, wawancara dan dokumentasi.

\section{HASIL DAN PEMBAHASAN}

\section{Motivasi Anggota}

Sesuai dengan indikator yang peneliti tetapkan, motivasi anggota secara garis besar yang peneliti temukan baik dari hasil observasi maupun wawancara sudah terlihat, namun motivasi yang dirasakan oleh kelompok anggota BKR di Desa air Lesing kurang pembaharuan yang bersifat kreativitas dari panitia pelaksana program
BKR. sehingga dengan kurangnya kecakapan dari panitai membuat anggota kelompok BKR ini merasa jenuh dengan kegiatan yang disajikan hanya sebatas kegiatan yang terlalu sering diselenggarakan yang tidak maksimal dalam membangkitkan kualitas kinerja kelompok.

Berdasarkan hasil observasi peneliti yang di dapat tentang motivasi ketua kelompok BKR di desa Air Lesing kurangnya kreativitas dari panitia pelaksana sehingga banyak ibu-ibu yang merupakan anggota kelompok merasa jenuh dan malas untuk berpartisipasi dalam kegiatan BKR itu sendiri. Mereka sendiri bingung harus memulai serta membuka kegiatan tersebut karena apa yang disarankan oleh anggota lambat diverifikasi sehingga jangka waktu menunggu yang membuat anggota kelompok lebih mensosialisasikan kegiatan BKR dengan cara mereka tanpa pantauan dari panitia. Dalam mengefektifkan kegiatan BKR di Desa Air Lesing mengandalkan ketangkasan ketua kelompok yang harus bergerak cepat sebelum motivasi dari anggota kelompok secara keseluruhan melemah dan bisa mengakibatkan non efektif untuk kegiatan BKR di Desa Air Lesing.

Dari uraian di atas dapat disimpulkan bahwa motivasi anggota menjadi hal yang penting dalam pengembangan sebuah kelompok untuk melaksanakan suatu program. Sedangkan untuk program yang belum berjalan maka tidak dapat diketahui bagaimana kemampuan mereka dalam melaksanakan program tersebut seperti halnya program BKR desa air lesing. Program ini belum berjalan dikarenakan masih tahap pembentukkan. Padahal sudah 1 (satu) tahun terbentuk yang seharusnya sudah ada kegiatan minimal sosialisasi dari tim penyuluh kepada anggota BKR dengan kreativitas dari pihak panitia penyelenggara yang dapat meningkatkan keinginan masyrakat untuk tetap berada dalam program ini.. namun karena program ini masih sebatas kelompok maka 
kemampuan anggota BKR belum dapat dikatakan efektif.

\section{Pemberdayaan Anggota}

Berdasarkan hasil observasi yang peneliti dapatkan di lokasi penelitian yaitu desa air Lesing terutama pada kelompok Bina Keluarga Remaja Desa Air Lesing, belum ada secara maksimal yang menerapkan langkah pemberdayaan anggota dikarenakan sulitnya mengumpulkan masyarakat desa air lesing karena mereka menginginkan kegiatan yang tidak bersifat formal secara terus menerus. Hal ini yang membuat masyarakat lebih memilih kegiatan mereka dibandingkan program BKR. hal tersebut juga berdampak pada anggota BKR itu sendiri yang menilai pelaksanaan program BKR tidak dapat maksimal apabila dana untuk pelaksanaan program tidak maksimal atau menyeluruh.

Berdasarkan hasil observasi, wawancara dan dokumentasi tentang Pemberdayaan anggota kelompok BKR Desa Air Lesing ialah :

1. Tidak adanya keterampilan yang berdampak pada tingkat kreativitas yang melemah padahal hal ini yang dapat dijadikan nilai tambah dalam pelaksanaan program BKR dari kelompok BKR Desa Air Lesing

2. Kurangnya kepercayaan yang penuh terhadap anggota sehingga kinerja merekapun terbatas.

3. Kurangnya kualitas dalam menerapkan suatu hal yang dapat menciptakan keinginan sehingga dari keinginan tersebut mereka dapat dengan mudah menciptakan alur untuk mencapai tujuannya.

Berdasarkan hasil observasi dan wawancara yang peneliti lakukan, dapat disimpulkan struktur anggota BKR sama dengan apa yang tercantum di SK yaitu terdiri dari ketua kelompok, sekretaris, bendahara dan anggota kelompok serta pelapor. Sesuai dengan yang ditetapkan oleh
BKKBN melalui Direktorat Bina Ketahanan Remaja. Yang menjelaskan bahwa untuk struktur kelompok dibuat sama dari BKR tingkat Pusat sampai pada Pedesaan. Yang membedakannya hanyalah profesi orang yang menduduki jabatan ketua Kelompok sampai pada anggotanya. Jika dari tingkat pusat pelaksana kegiatan BKR ini berprofesi sebagai ketua PKK sampai pada kepala dinas terkait. Tujuan dibuatnya struktur anggota agar nama yang diberikan tanggung jawab dapat mnejalankan tugasnya sesuai dengan yang telah ditetapkan oleh program BKR misalnya ketua kelompok yang menjadi kunci keefektifan pelaksanaan program memainkan peran kecakapannya dalam mengelola program BKR agar program tersebut dapat mencapai tujuan dan sasarannya. Yang dibantu oleh sekretaris, bendahara dan anggota kelompok yang diharapkan memiliki kreativitas dalam memasarkan program BKR kepada masyarakat. Namun karena program BKR di desa Air Lesing belum berjalan secara maksimal struktur anggota hanya nama di atas kertas namun belum ada realisasi hasil kerja dari kelompok BKR desa air lesing.

\section{KESIMPULAN}

1. Motivasi Anggota

Berdasarkan hasil penelitian melalui observasi, wawancara serta dokumentasi melalui fokus penelitian Motivasi anggota yang ditinjau dari ekspektasi, instrumentalis dan valensi dapat disimpulkan bahwa motivasi anggota menjadi hal yang penting dalam pengembangan sebuah kelompok untuk melaksanakan suatu program. Sedangkan untuk program yang belum berjalan maka tidak dapat diketahui bagaimana kemampuan mereka dalam melaksanakan program tersebut seperti halnya program BKR desa Air Lesing. Program ini belum berjalan dikarenakan masih tahap pembentukkan. Padahal sudah 1 (satu) tahun terbentuk yang seharusnya sudah ada kegiatan minimal sosialisasi dari 
tim penyuluh kepada anggota BKR dengan kreativitas dari pihak panitia penyelenggara yang dapat meningkatkan keinginan masyarakat untuk tetap berada dalam program ini.. namun karena program ini masih sebatas kelompok maka kemampuan anggota BKR belum dapat dikatakan efektif.

2. Pemberdayaan Anggota

Berdasarkan hasil penelitian melalui fokus penelitian pemberdayaan anggota ditinjau dari Desire, Trust, Confident dan Communication tidak terdeskripsi karena kurangnya kecakapan yang maksimal dan sangat berkaitan dengan tujuan dari program BKR dari panitia pelaksana kepada anggota BKR. dengan permasalahan ini, maka pemberdayaan anggota BKR di Desa Air Lesing Tidak Efektif.

\section{SARAN}

Saran adalah suatu masukan atau rekomendasi yang dibuat untuk menyempurnakan hasil dari sebuah penelitian. Untuk mencapai tujuan yang telah di tetapkan oleh BKKBN tentang Pelaksanaan Program BKR, peneliti merumuskan beberapa saran sesuai dengan temuan yang peneliti dapatkan di lokasi penelitian :

1. Diharapkan Pihak Koordinator Lapangan

KB Kecamatan Muara Beliti lebih bisa menempatkan cara yang efektif dalam pelaksanaan dengan metode inovasi

2. Anggota BKR membangun hubungan sinergi dengan pihak koordinator lapangan KB selaku penyuluh terutama kegiatan penyuluhan tentang program BKR agar tujuan dari program BKR dapat tercapai.

3. Agar program ini diketahui masyarakat serta dapat lebih menarik minat orang tua untuk mengetahui lebih jauh tentang Program BKR ini dengan membuat spanduk, brosur dan gambar-gambar. Selain itu, pendekatan yang yang dilakukan oleh pengelola dan pelaksana sebaiknya ditunjukkan dengan sikap peduli, ramah dan terbuka sehingga para orang tua pun tertarik untuk mengikuti kegiatan BKR dan penambahan jumlah kader yang ada dapat bertambah dengan diberikan pelatihan agar dapat membantu Petugas Penyuluh dalam mengembangkan BKR.

4. Berdasarkan UU No. 14 tahun 2008, pihak DPP-KB selaku penyelenggara utama dalam pelaksanaan program BKR, wajib untuk lebih transparansi mengenai anggaran dana program BKR yang telah dipersiapkan oleh Pemerintah Daerah. Sehingga tidak ada kecurigaan publik terhadap pengelolaan dana.

5. Struktur organisasi BKR disesuaikan dengan prosedur yang ditetapkan oleh BKKBN melalui buku pedoman pengelolaan BKR. sehingga struktur yang tercantum di SK dapat dipertanggung jawabkan.

\section{DAFTAR PUSTAKA}

[1] BKKBN. (2012). Pedoman Pengelolaan Bina Keluarga Remaja. Jakarta: BKKBN.

[2] BKKBN. (2012). Pedoman Pengelolahan BKR. Jakarta.

[3] BKKBN. (2012). Peraturan Kepala BKKBN Nomor : 109/PER/F2/2012.

[4] BKKBN. (2019, desember Senin). Jumlah Kelompok BKR di Indonesia. Retrieved from http://www.bkkbn.go.id.

[5] BKKBN, D. C. (2017). Batasan Usia Pernikahan.

[6] DPP-KB. (2019). Informasi Kegiatan BKR Kecamatan Muara Beliti.

[7] DPP-KB. (2019). Jumlah Kelompok BKR Musi Rawas. 
[8] Hasibuan, M. P. (2018). Manajemen Sumber Daya Manusia. In M. P. Hasibuan, Manajemen Sumber Daya Manusia. Jakarta: Bumi Aksara.

[9] Ibtia, A. (2016). Efektivitas Pelaksanaan Program Bina Keluarga Remaja Dalam Upaya Pendewasaan Usia Pernikahan. Belitbang.

[10] Siagian, S. P. (2018). Manajemen Sumber Daya Manusia. In S. P. Siagian, Manajemen Sumber Daya Manusia. Bandung : Alfabeta.

[11] Siswanto. (2016). Pengantar Manajemen. In Siswanto, Pengantar Manajemen. Jakarta: Bumi Aksara.

[12] Sudarwan, D. (2012). Motivasi Kepemimpinan \& Efektivitas Kelompok. In D. Sudarwan, Motivasi Kepemimpinan \& Efektivitas Kelompok. Rineka Cipta.

[13] Sugiyono. (2017). Metode Penelitian Kuantitatif dan Kualitatif. In Sugiyono, Metode Penelitian Kuantitatif dan Kualitatif. BNdung: Alfabeta.

[14] Sukalele, D. (2017, November 17). pemberdayaan masyarakat miskin. Retrieved from wordpress.com.

[15] SumSel, B. (2019). Jumlah Kelompok BKR Sumsel. SUMSEL: BKKBN.

[16] Sunyoto, D. (2015). Manajemen dan Pengembangan Sumber Daya Manusia. Yogyakarta: Center for Academic publishing Service.

[17] Suparno. (2015). Manajemen Pengembangan Sumber Daya Manusia. In Suparno, Manajemen Pengembangan Sumber Daya Manusia. Jakarta: Pustaka Pelajar.
[18] Sutrisno, E. (2016). Manajemen Sumber daya Manusia. In E. Sutrisno, Manajemen Sumber daya Manusia. Jakarta: Kencana Prenada Media Group.

[19] Terry, G. R. (2016). Dasar-dasar Manajemen. Jakarta: Bumi Aksara.

[20] Thoha, M. (2017). Perilaku Organisasi. In M. Thoha, Perilaku Organisasi. Jakarta: Rajawali Pers. 